\title{
Heat shock proteins development in different stages of Schistocerca gregaria as response to heavy metals intoxication
}

\author{
Hesham A. Yousef ${ }^{1^{*}}$, Amira Afify ${ }^{1}$, Afaf Abdel Meguid ${ }^{1}$, Hany M. Hassan ${ }^{2}$ \\ ${ }^{1}$ Entomology Department, Faculty of Science, Cairo University, Egypt; ${ }^{*}$ Corresponding Author: heshamyousef.eg@gmail.com \\ ${ }^{2}$ Agriculture Research Center, Ministry of Agriculture, Egypt
}

Received 31 December 2010; revised 14 February 2011; accepted 16 February 2011.

\begin{abstract}
The induction of heat shock proteins in different stages of $S$. gergaria exposed to long and short term contamination with heavy metals, $\mathrm{Cd}$ and $\mathrm{Pb}$ in food was determined, revealing a prominent variable effect in response to the term of exposure and the type of contamination. HSP 70 was specially quantified and characterized to reveal the probability of using HSP as a biomarker for pollution.
\end{abstract}

Keywords: Hsps; Hsp70; Heavy Metals; Cd; Pb; S. Gergaria

\section{INTRODUCTION}

Heavy metals are among the most problematic causes of water, soil and plant pollution. They enter the ground water and surface water through seepage from household waste, and a number of industries. In the case of soil pollution, terrestrial insects, including orthopteran species, may provide good samples to evaluate the mutagenic effects of some environmental contaminants, and may be considered suitable bioindicators [1-4].

Cadmium and lead are the most dangerous, carcinogenic, widespread heavy metals, released and accumulated in the environment. Their toxicity for epigeic insect depends mainly on the way of their entrance to the body cavity and the most important is their intake with food. Insects are able to accumulate metals in intracellular granules and/or to some extent control this route, by selecting the quality of food, mainly plants containing less metal, by avoiding plant parts which are more contaminated, or simply by rejecting metals with excreta $[5,6]$. Insects, which develop partly in the soil, are also exposed directly to metal ions present in the soil water. Among them are many grasshopper species which lay egg-pods directly in the soil.
Exposure of organisms to different environmental pollutants has been found to induce a variety of stress response including the heat shock proteins [7]. Under normal, unstressed conditions, the constitutively present stress proteins are essential for cell viability, they participate in protein folding and assembling, metabolic processes, and cell growth and development [8].

Cytoprotective functions and immune response have been attributed to HSPs and, in particular to the HSP 70 family [9-11].

The aim of the present work was to determine the induction of heat shock proteins in S. gergaria exposed to heavy metals, $\mathrm{Cd}$ and $\mathrm{Pb}$, with special quantifying and characterizing the HSPs 70 to reveal the probability of using HSP as a biomarker for pollution.

\section{MATERIALS AND METHODS}

\subsection{Colonization of S. Gregaria}

Locusts were obtained from the laboratory colonies maintained at the Entomology Department, Faculty of Science, Cairo University. The locusts were reared in wooden cages at $(32 \pm 2)^{\circ} \mathrm{C}, 50 \%-60 \% \mathrm{RH}$ and $16 \mathrm{hrs}$ day light. A daily supply of fresh grass, clover plant was supplied to the locusts. Packed moist sterilized sand in suitable glass containers about $7 \mathrm{~cm}$ in diameter and 10 $\mathrm{cm}$ deep were prepared for egg-laying.

\subsection{Heavy Metals Treatment}

Living individuals of $S$. gregaria of the $4^{\text {th }}, 5^{\text {th }}$ instars, and newly emerged (NEA) (4 days old) and mature (15 days old) adult (MA), fed on treated clover (their stems were previously immersed for $24 \mathrm{hrs}$ in distilled water containing $25 \mathrm{mg}$ and $50 \mathrm{mg} / \mathrm{L}$ of $\mathrm{CdCl}_{2}$ and $\mathrm{PbCl}_{2}$, to allow the clover to absorb contaminated water) or on untreated clover, were collected from their respective cage. 


\subsection{Sample Preparation for SDS-PAGE and Elisa Test}

Living individuals of $S$. gregaria of the $4^{\text {th }}, 5^{\text {th }}$ instars, and newly emerged (4 days old) and mature (15 days old) adult, fed on treated clover (their stems were previously immersed for $24 \mathrm{hrs}$ in distilled water containing $25 \mathrm{mg}$ and $50 \mathrm{mg} / \mathrm{L}$ of $\mathrm{CdCl}_{2}$ and $\mathrm{PbCl}_{2}$, to allow the clover to absorb contaminated water) and untreated clover were collected from their respective colony.

One $\mathrm{g}$ of each instar was homogenized in $1 \mathrm{ml}$ of saline solution using Teflon in glass homogenizer. The body extract was centrifuged at 12,000 rpm for $15 \mathrm{~min}$ at $4^{\circ} \mathrm{C}$, using Kubota cooling high speed centrifuge. Total protein concentration was determined Spectrophotometrically according to the method described by Bradford [12], using bovine serum albumin as standard. The optical density of the protein sample was measured at $595 \mathrm{~nm}$ versus the blank.

\subsection{SDS-Polyacrylamide Gel Electrophoresis}

SDS-PAGE was performed in a slab gel apparatus utilizing the discontinuous system described by Laemmli [13].

$250 \mu \mathrm{g}$ total protein of each sample (diluted 1:1 (vol: vol) with treatment buffer and boiled in water bath for 2.5 minutes) were loaded with a drop of tracking dye in each lane. Similarly protein marker was loaded on the gel beside the samples. Electrophoresis was running at 80 volt and $30 \mathrm{~mA}$, the gels were stained for $0.5 \mathrm{~h}$ in COBB stain, and excess dye was removed by placing the gel in distaining solution. The gels were scanned, using the densitometric scanner by which the relative concentration and Mwt values of each characteristic band can be deduced using protein molecular weight marker (28.5-116 kDa) including B-galactosidase, Phosphorylase $b$, Bovine serum albumin, Alcohol dehydrogenase and carbonic anhydrase with the molecular weights: 116, $97.4,66.2,37.6$ and $28.5 \mathrm{kDa}$ respectively.

\subsection{Detection of the Hsp 70 Using the ELISA Method}

The components of Stress Xpress TM Hsp 70 ELISA kit wer used at room temperature. Lyophilized recombinant Hsp 70 standard was centrifuged before and after rehydration. Dilute rehydrated recombinant Hsp 70 standard and samples in sample diluents. Add $100 \mu \mathrm{l}$ prepared standards and samples in duplicate to wells of Hsp 70 immunoassay plate. Cover immunoassay plate; incubate plate at room temperature for 2 hours. Wash wells with $1 \mathrm{X}$ Wash Buffer. Add $100 \mu$ diluted Biotin Anti-Hsp 70 to each well. Cover immunoassay plate.
Incubate plate at room temperature for 1 hour. Wash wells $6 \mathrm{X}$ with $1 \mathrm{X}$ Wash Buffer. Add $100 \mu$ l diluted Avidin-HRP Conjugate to each well. Cover immunoassay plate. Incubate plate at room temperature for 1 hour. Wash wells 6X with $1 \mathrm{X}$ Wash Buffer. Add $100 \mu \mathrm{l}$ TMB Substrate to each well, incubate at room temperature for $10 \mathrm{~min}$, and add $100 \mu 1$ Acid Stop Solution to each well. Measure absorbance at $450 \mathrm{~nm}$, and plot the Hsp 70 standard curve and calculate hsp 70 sample concentrations.

\section{RESULTS AND DISCUSSION}

\subsection{Effect of $\mathrm{Cd} \& \mathrm{~Pb}$ on $4^{\text {th }}$ Instar Nymph Proteins}

The SDS-PAGE analysis of the whole body proteins of $4^{\text {th }}$ instar $S$. gregaria exposed for long term (from newly hatched $1^{\text {st }}$ nymphal instar) to low and high concentrations of $\mathrm{Cd}$ and $\mathrm{Pb}$, showed that the most prominent variations appeared in the protein bands, Mw.61 and $49 \mathrm{KDa}$ (group 60 and 50), revealing that the highest amount of induced proteins were expressed in these groups (Figure 1(a)).

The short term exposure of the $4^{\text {th }}$ instar $S$. gregaria to heavy metals (4 days before collecting) showed an increase in concentration of the protein bands, Mw. 88, 77 and $57 \mathrm{KDa}$, in relation to control. Also, the protein bands, Mw. 67, 53, $45 \mathrm{KDa}$, almost appeared in case of $\mathrm{Cd}$ and in $\mathrm{Pb}$ treatment (Figure 1(b)). This result revealed the induction of new sets of proteins belong to groups $60,50,40 \mathrm{KDa}$, and increase of protein concentrations belonging to groups 80 and $70 \mathrm{KDa}$ (Figure 1(b)).

\subsection{Effect of $\mathrm{Cd} \& \mathrm{~Pb}$ on $5^{\text {th }}$ Instar Nymph Proteins}

The long term exposure of $5^{\text {th }}$ instar nymph to heavy metals showed the appearance of protein band, Mw. 26 $\mathrm{KDa}$, only in the two treatments of high \& low $\mathrm{Pb}$ concentrations (Figure 2(a)). A prominent variation was observed including the increase of concentrations of protein bands (67 and $34 \mathrm{KDa}$ ) after low $\mathrm{Cd}$ treatment, protein bands ( 52 and $39 \mathrm{KDa}$ ) after treatment of high Cd. Also, Low and high concentration of lead treatment has inducing effect by expression of new protein band (Mw. $26 \mathrm{KDa}$ ).

SDS-PAGE of the whole body of $5^{\text {th }}$ instar, S. gregaria exposed to short term contamination with heavy metals showed disappearance of proteins with Mw. 121, 97, 73, 65 and $58 \mathrm{KDa}$ in low $\mathrm{Pb}$ treatment, and appearance of protein band, Mw $44 \mathrm{KDa}$. Newly expressed protein bands, Mw. 47 and $36 \mathrm{KDa}$ were newly expressed 


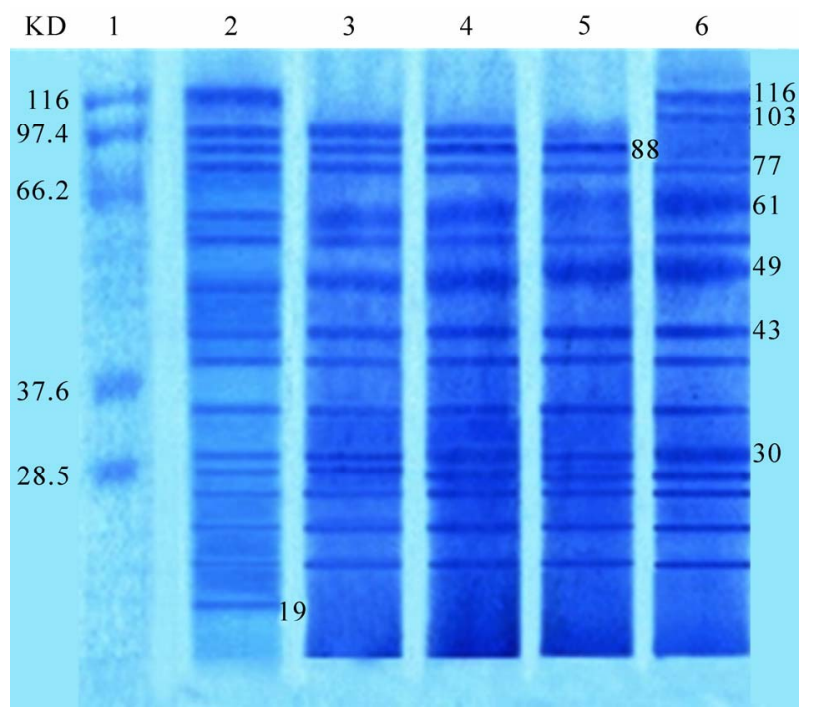

(a)

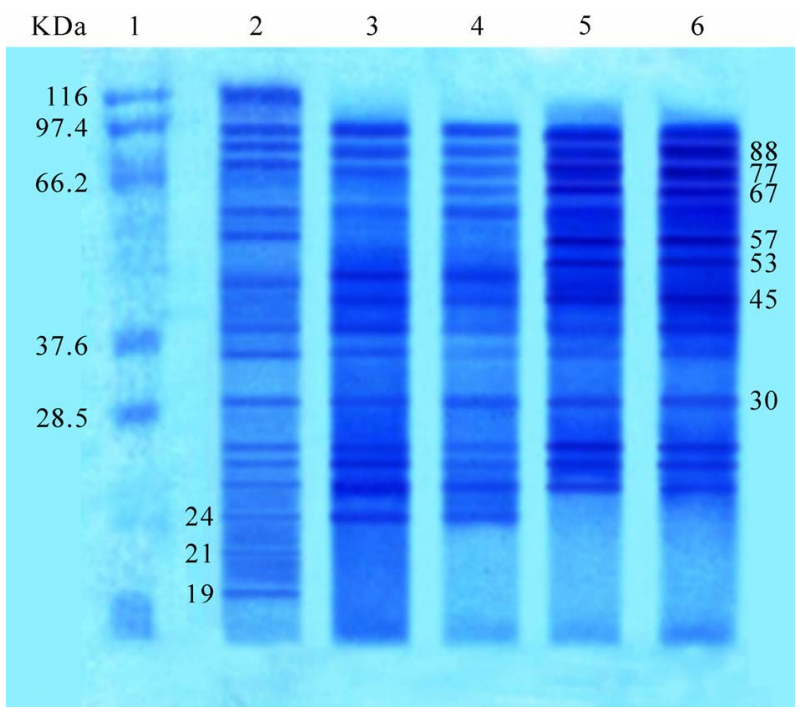

(b)

Figure 1. SDS-PAGE of whole body tissue proteins of $4^{\text {th }}$ instar $S$. gregaria under normal and heavy metal stress conditions for (a) long term exposure and (b): short term exposure. Lane 1: Mw. marker; Lane 2: normal; Lane 3: low Cd; Lane 4: high $\mathrm{Cd}$; Lane 5: low $\mathrm{Pb}$ and Lane 6: high $\mathrm{Pb}$.

after all treatments, which were absent in control.

On the other hand, the short exposure to heavy metals revealed that, induction of new set of proteins as in band, $125 \mathrm{KDa}$ after high $\mathrm{Cd}$, bands, Mw. 47 \& $36 \mathrm{KDa}$ after $\mathrm{Cd}$ and $\mathrm{Pb}$ treatments. Increased concentration of other protein bands, were observed as in bands, 34 and 24 KDa (Figure 2(b)).

It is clear that analysis of the SDS-PAGE of the whole body proteins of $5^{\text {th }}$ instar $S$. gregaria after long and short exposure to heavy metals revealed the increase in concentration of proteins with small Mw families which

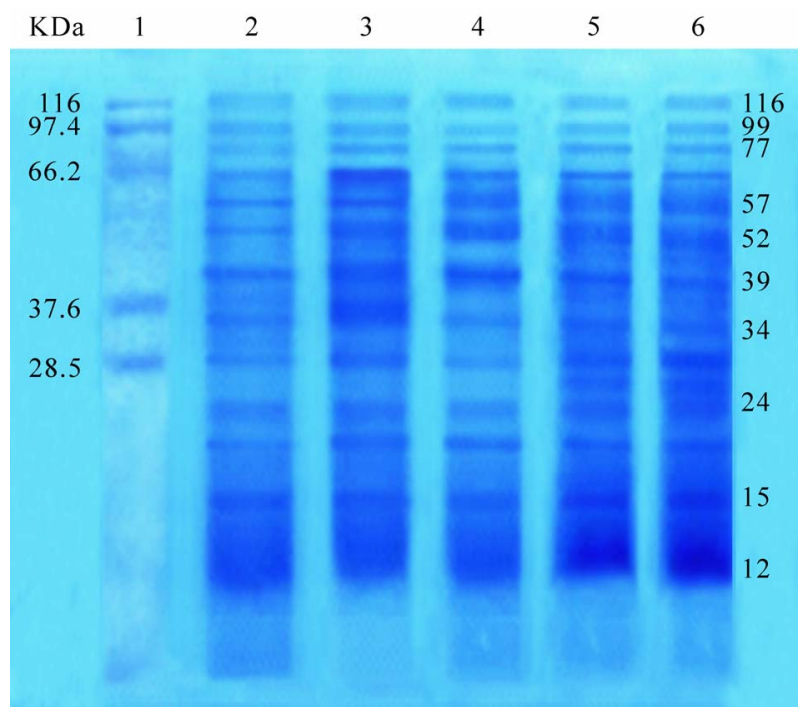

(a)

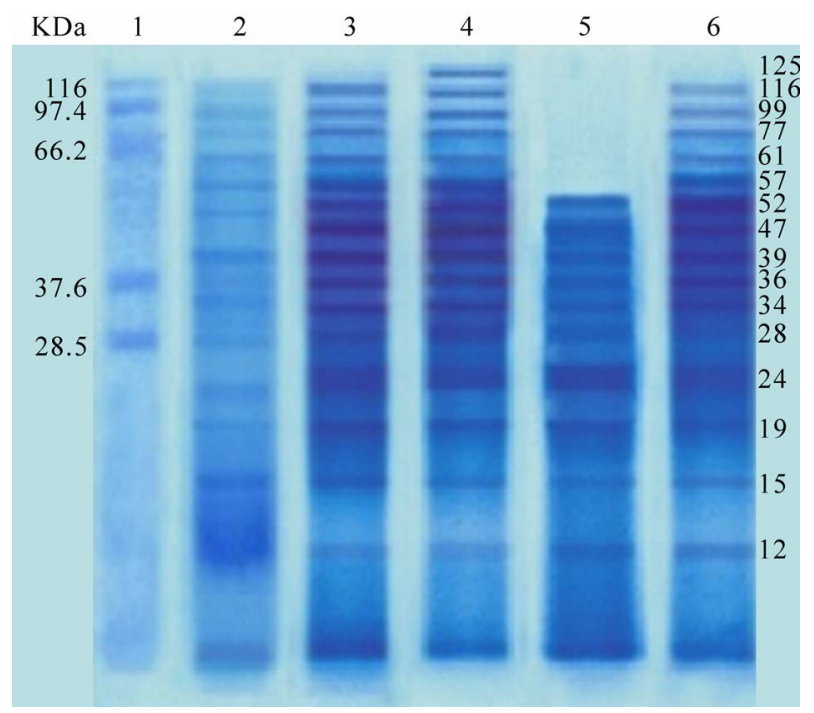

(b)

Figure 2. SDS-PAGE of whole body tissue proteins $5^{\text {th }}$ instar of $S$. gregaria under normal and heavy metal stress conditions for (a): long term exposure and (b): short term exposure. Lane 1: Mw. marker; Lane 2: normal; Lane 3: low Cd; Lane 4: high $\mathrm{Cd}$; Lane 5: low $\mathrm{Pb}$ and Lane 6: high $\mathrm{Pb}$.

may be included in small Hsps 20, 30 \& $50 \mathrm{KDa}$. There was a low increase in concentration of protein bands, Mw. 77, $61 \& 57 \mathrm{kDa}$ observed in treatments of short exposure to heavy metals and in low Cd concentration in long term exposure to heavy metals.

\subsection{Effect of $\mathrm{Cd} \& \mathrm{~Pb}$ on Newly Emerged Adult (NEA) Proteins}

The proteins of the whole body tissue of NEA after long exposure of heavy metals revealed appearance of 
protein band, Mw $7 \mathrm{KDa}$ and disappearance of bands, Mw 117 and $99 \mathrm{KDa}$ in treatment of high $\mathrm{Cd}$, and low $\mathrm{Pb}$ concentration.

Figure 3(a) showed that, there was a high expression of proteins, as in bands with Mw. 77 and $57 \mathrm{KDa}$, especially in high $\mathrm{Cd}$ and low $\mathrm{Pb}$ treatments. The protein bands, Mw. 34, 15 \& $12 \mathrm{KDa}$ over expressed in the $\mathrm{Cd}$ and $\mathrm{Pb}$ treatments in relation to the normal specimen. Also, proteins, Mw. 117 and 99 KDa disappeared in treatment of high $\mathrm{Cd}$ and low $\mathrm{Pb}$ concentrations. On the other hand, the protein band, Mw.7 KDa appeared only in the two previous treatments. Unlike that of long term exposure, short term exposure caused over-expression in some proteins as in the band with Mw. $55 \mathrm{KDa}$ under the effect of high $\mathrm{Cd}$ concentration, and the two treatments of high and low $\mathrm{Pb}$ concentrations, also band, Mw. 12 KDa was over expressed in all treatments than control.

The analysis of the whole body proteins of NEA, $S$. gregaria separated by electrophoresis, after short term exposure of heavy metals revealed the higher induction of protein bands with Mw. 57, 15 and $12 \mathrm{KDa}$. High Cd and low $\mathrm{Pb}$ treatments caused more induction of the proteins, Mw. 34 and $24 \mathrm{KDa}$ (Figure 3(b)).

The long term exposure of NEA, $S$. gregaria to heavy metals (Figure 4(a)) induced over expression of the protein band with $\mathrm{Mw} .72 \mathrm{KDa}$ (except in the low $\mathrm{Cd}$ treatment) and protein bands (Mw. 49\& $12 \mathrm{KDa})$. On the other hand, lower expression in the protein band (Mw. $32 \mathrm{KDa})$ was observed.

All the bands are similar in all treatments and control. The main difference between them was in the concentrations of bands, Mw. 49 and $32 \mathrm{KDa}$. There was over expression in all treatments than control but in band, Mw. $39 \mathrm{KDa}$, there was down expression in the treatment of low concentration $\mathrm{Cd} \& \mathrm{~Pb}$ with the same ratio than control (Figure 4(b)).

The analysis of the whole body proteins of mature adult $S$. gregaria separated by electrophoresis showed that the most prominent variations due to the effect of heavy metals after short exposure were observed in the protein bands with Mw. $72 \mathrm{KDa}$. This reflects the highest induction of this protein band in all treatments in relation to the control (about 4-6 folds).

Stressful conditions are frequently accomplished by disturbances and alterations of cellular functions at various levels with the resulting situation associated with the increase in stress proteins [14]. These functions include the folding and maintenance of structural proteins in various intracellular compartments, refolding the misfolded proteins, translocation of proteins across membranes, prevention of protein aggregation, and degradation of unstable proteins $[9,15]$, help in the adaptation of insects frequently, or continuously exposed to severe stress [16-18], involved in generating immune response [11]. Hsp 70 is also known to facilitate antigen presentation in cells such as macrophages and dendrites [10].

In the present work, proteins from the whole body of $S$. gregaria were examined in the term of heavy metal contamination in both long term exposure (heavy metal accumulation), and short term exposure through the developmental stages from $4^{\text {th }}$ instar to fully mature adult. SDS-PAGE and their analyses were obtained, revealing prominent changes in certain major proteins reflecting the elevation of the present polypeptides or expression of

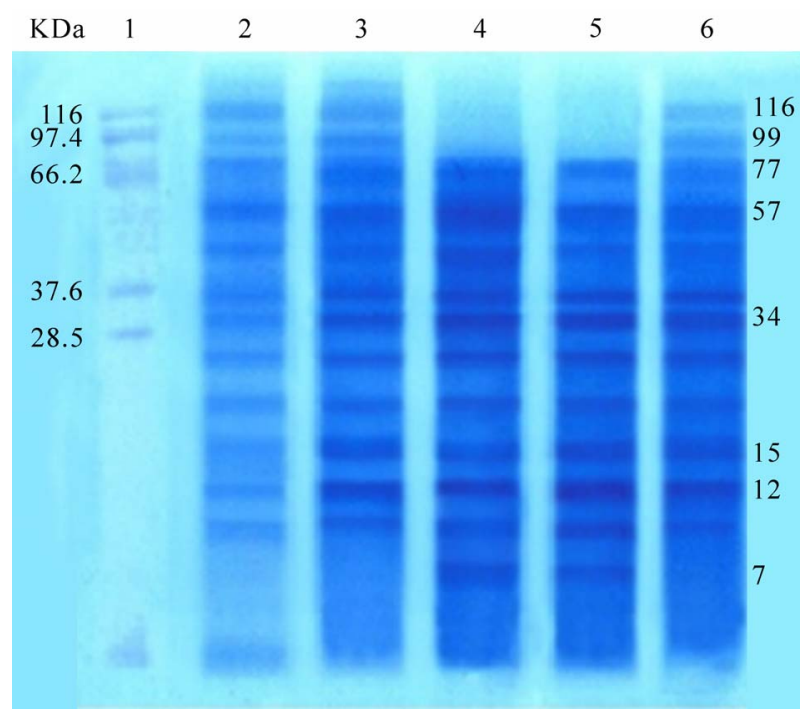

(a)

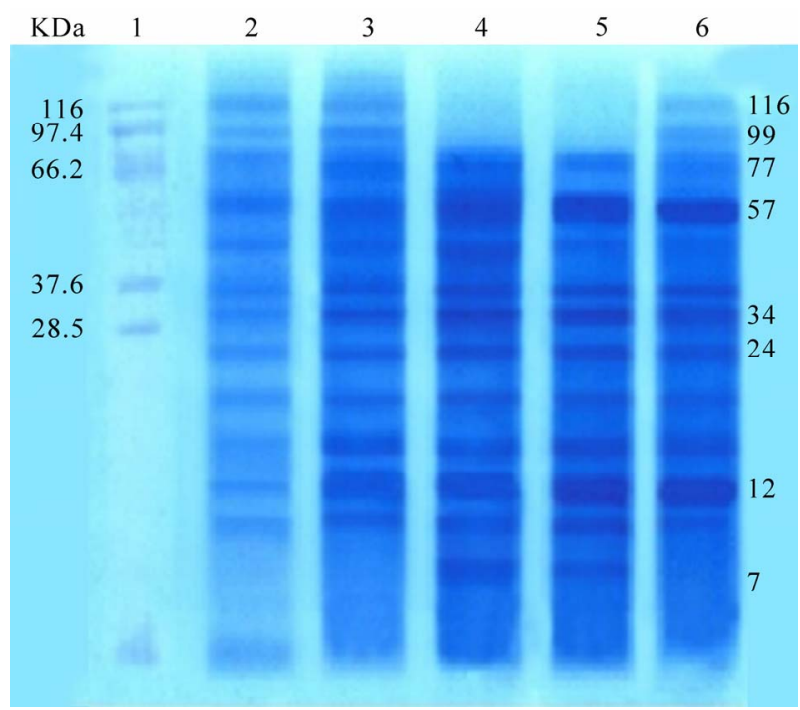

(b)

Figure 3. SDS-PAGE of whole body tissue proteins of NEA $S$. gregaria, under normal and heavy metal stress conditions for (a): long term exposure and (b): short term exposure. Lane 1: M.wt marker; Lane 2: normal; Lane 3: low Cd; Lane 4: high $\mathrm{Cd}$; Lane 5: low $\mathrm{Pb}$ and Lane 6: high $\mathrm{Pb}$. 


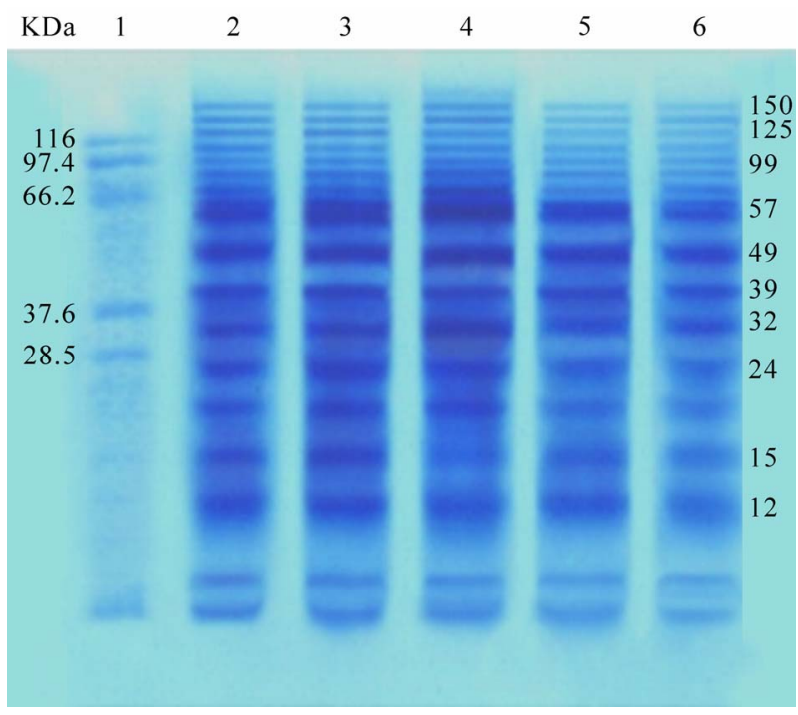

(a)

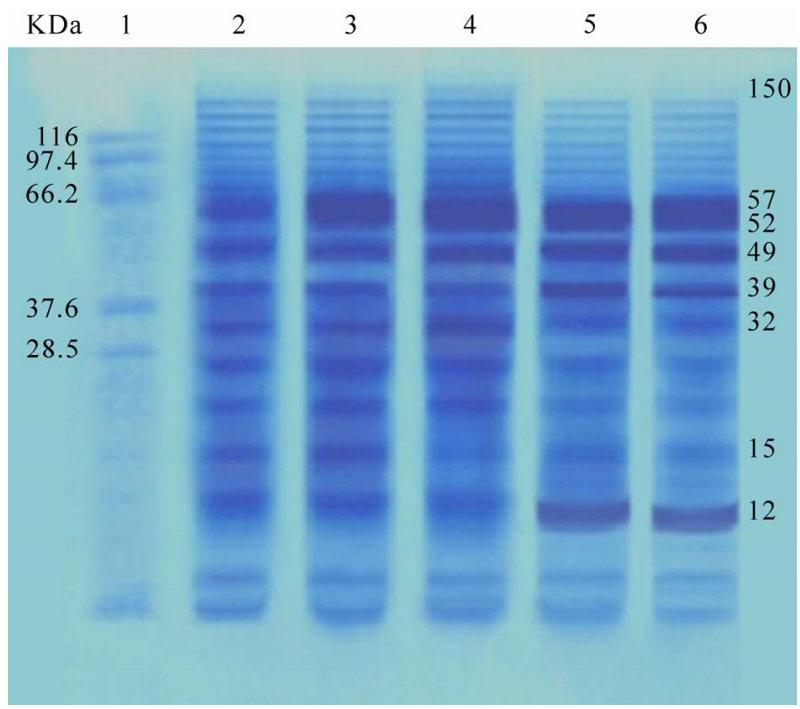

(b)

Figure 4. SDS-PAGE of whole body tissue proteins of mature adult $S$. gregaria, under normal and heavy metal stress conditions for (a): long term exposure and (b): short term exposure. Lane 1: Mw. marker; Lane 2: normal; Lane 3: low Cd; Lane 4: high $\mathrm{Cd}$; Lane 5: low $\mathrm{Pb}$ and Lane 6: high $\mathrm{Pb}$.

new sets of proteins (Hsps), in different molecular weight groups. These Hsps ranged from high $(90 \mathrm{KDa})$ to low molecular weight $(12 \mathrm{KDa})$. Based on the criterion that the synthesis (appearance) or elevations of these polypeptides were stimulated after heat shock (or environmental stress as heavy metal contamination), they are referred to as heat shock proteins (Hsps) or stress proteins [19]. They belong to the most well known families of Hsp 100, Hsp 90, Hsp 70, Hsp 60, Hsp 40, and the small Hsps (below 30KDa) [20].

The obvious increase of small Hsps levels may have resulted from the characteristic and relatively stable breakdown products of Hsp 70, i.e., they are proteolytically reduced to small Hsps [21,22].

Hsps, which are a quite divergent domain consist of 80-100 amino acids and can form high molecular weight polymeric structures that may be necessary for function within the cell. During cellular stress, Hsps bind to unfolded or damaged proteins, inhibit their aggregation and maintain their client protein in a soluble and folding competent state such that they can be refolded to their native conformation by other ATP-dependent chaperones [23].

Hsps 52-57 and 62-66 KDa were almost the major proteins stimulated by the contamination with cadmium and lead metals; their expression elevated or newly synthesized. Another prominent induction in small Hsps; 12-15 and $24 \mathrm{KDa}$ were observed by the heavy metal stress (Figures 1-4). Cadmium was reported to be induced the expression of heat shock proteins (Hsps) and metallothioneins [24-26].

Also it was very clear that short exposure to the heavy metals was more effective than long exposure in elevation or inducing protein synthesis and rather a decrease in some protein levels (Figures 1-4). The lack of intensive synthesis of stress proteins indicates that, in S. gregaria, the protective role of these Hsps against the action of toxic substances does not function or alternatively insects living in the contaminated area or exposed to toxic materials for long times have adapted to the level of existing contamination and not only do not synthesis more Hsps but rather decrease synthesis [27,4].

Adaptive changes in Hsp expression during several days also support the ecological significance of Hsps in natural populations $[28,29]$. In different species of Drosophila, it was shown that expression of Hsp 70 was lower in lines frequently or continuously exposed to sever stress (16-18]. The interpretation was that the costs of Hsp expression in populations frequently exposed to stress outweighed the benefits and that stress adaptation was achieved through some other means. The same pattern was subsequently found in natural population of Drosophila [30] and in soil invertebrates exposed to heavy metals [31]. According to these findings, the adaptation role of Hsps in connection to environmental stress resistance seems to occur during periods of relatively rare, unexpected extreme stress exposures and not during every day environmental fluctuations. Other mechanisms of adaptation to stressful conditions are selected for under chronic stressful environmental conditions [17,32].

It was suggested that the low Hsp induction was caused by a more pronounced need for chaperones in order to maintain optimal cell function and homeostasis. 
The up-regulation of Hsps in addition to being an important part of the response to sudden extreme stress exposures is of ecological relevance on a much wider scale with respect to less severe but regular incidences of stress [33].

In conclusion, heat shock proteins are important in relation to stress resistance and adaptation to the environment. The regulation of Hsp is influenced by both environmental and genetic stress factors.

\subsection{Estimation of Hsp 70}

Data analysis of the Hsp 70 detected, using ELISA technique with the monoclonal antibody (anti-Hsp70), revealed that the onset development of Hsp expression at the different instars of $S$. gregaria, in both the control and the insects exposed to heavy metals exhibit Hsp 70.

The Hsp 70 expressed in the $4^{\text {th }}$ instar are shown in (Table 1), in the long term exposure to heavy metals $\mathrm{Cd}$ and $\mathrm{Pb}$ in both low and high concentrations. The increases of the expressed Hsp 70 were significant at the high $\mathrm{Cd}$, and low $\mathrm{Pb}$ concentrations (about 2 folds to control). A non significant change in the low $\mathrm{Cd}$, and high $\mathrm{Pb}$ concentrations were observed. On the other hand, the short term exposure to heavy metals showed significant increase in the expressed Hsp 70 with respect to the control.

The highest increase in Hsp expression was observed in the treatment with low $\mathrm{Cd}$ concentration at short term exposure (5 times more than control) and in contrast, the lowest expression in Hsp 70 was observed in the treatment with low $\mathrm{Cd}$ concentration at long term exposure (19.8\% to control). At the short term exposure, it is clear that, the expression level of Hsp 70 at high concentration of $\mathrm{Cd}$ and $\mathrm{Pb}$ was the same, but at long term exposure, the high $\mathrm{Cd}$ concentration has an effect nearly equal to the effect of low $\mathrm{Pb}$ concentration.

The concentration of Hsp 70 detected in all treatments in $5^{\text {th }}$ instar exposed to heavy metals for long term increased significantly with respect to control, with an exception (insignificant increase) in low $\mathrm{Pb}$ concentra- tion (Table 1). The present data revealed that the Hsp 70 was highly expressed in insects exposed to heavy metals at short term exposure, and the highest increase of Hsp 70 expression was in low $\mathrm{Pb}$ concentration at short term exposure (12.27 folds more than control). At the $5^{\text {th }}$ instar, the effect of low $\mathrm{Pb}$ concentration was higher than low $\mathrm{Cd}$ concentration, but high $\mathrm{Cd}$ concentration was higher than high $\mathrm{Pb}$ concentration especially after short term exposure.

Newly emerged adult $S$. gregaria was the stage at which all treatments gave significant results of Hsp 70 elevation (Table 1), the highest Hsp 70 concentration expressed was observed at the treatment of high concentration of $\mathrm{Cd}$ at short term exposure (307.5\%) (3 folds). The first decrease in Hsp70 concentration was observed in the treatment of low $\mathrm{Pb}$ at long term exposure $(64.4 \%)$ (The decrease by $40 \%$ ), the data shows fluctuations.

In the mature adult $S$. gregaria, Hsp 70 concentration increased significantly in the long term exposure to high $\mathrm{Cd}$ concentration and low $\mathrm{Pb}$ concentration $(204.6 \%$ \& $123.5 \%$ ) (2 folds and $23.5 \%$ ), but the increment of Hsp 70 was insignificant at low Cd concentration (Table 1). The surprise was appeared in the high concentration of $\mathrm{Pb}$; at which a high decrease in Hsp 70 concentration was observed ( $96.6 \%$ decrease of the control). The short term exposure of this stage caused obvious increment of Hsp 70, but it was lower than that of other stages.

In the present work, the non stressed (control) insects expressed Hsp 70, which was considered previously as normal component of larval imaginal discs and found in normal Drosophila embryos [34], and in addition to the growing evidence that Hsps are present under non-heat shock conditions in specific developmental stages/cell types in different organisms [20].

In the present study, all stages showed higher Hsp 70 expression after short term exposure than that expressed after long term exposure. This was obvious in $5^{\text {th }}$ instar were the highest concentration of Hsp 70 was after short term exposure and the lowest Hsp 70 expression after long term exposure and this may be due to the fact that

Table 1. Concentrations of Hsp 70 in the body of different instars $S$. gregaria after long term and short term exposure to heavy metals.

\begin{tabular}{cccccccccc}
\hline \multirow{2}{*}{ Stage } & \multirow{2}{*}{ Control } & \multicolumn{4}{c}{ Long term exposure } & & \multicolumn{4}{c}{ Short term o exposure } \\
\cline { 3 - 10 } & & Low Cd & High Cd & Low Pb & High Pb & Low Cd & High Cd & Low Pb & High Pb \\
\hline $4^{\text {th }}$ & $1.06+.075$ & $1.27 \pm 0.145$ & $2.27 \pm 0.044^{*}$ & $2.3 \pm 0.058^{*}$ & $1.35 \pm 0.11$ & $5.7 \pm 0.12^{*}$ & $3.4 \pm 0.12^{*}$ & $4.5 \pm 0.18^{*}$ & $3.4 \pm 0.13^{*}$ \\
$5^{\text {th }}$ & $0.59+0.06$ & $1.35 \pm 0.145^{*}$ & $1.05 \pm 0.05^{*}$ & $0.677 \pm 0.077$ & $2.23 \pm 0.09^{*}$ & $6.65 \pm 0.11^{*}$ & $5.24 \pm 0.09^{*}$ & $7.24 \pm 0.06^{*}$ & $4.3 \pm 0.08^{*}$ \\
$\mathrm{NEA}$ & $1.74+0.08$ & $2.25 \pm 0.09^{*}$ & $2.37 \pm 0.1^{*}$ & $1.12 \pm 0.122^{*}$ & $2.46 \pm 0.053^{*}$ & $4.3 \pm 0.13^{*}$ & $5.35 \pm 0.06^{*}$ & $3.35 \pm 0.07^{*}$ & $3.75 \pm 0.09^{*}$ \\
$\mathrm{MA}$ & $1.036+0.1$ & $1.063 \pm 0.07$ & $2.12 \pm 0.09^{*}$ & $1.28 \pm 0.09^{*}$ & $0.035 \pm 0.008^{*}$ & $4.25 \pm 0.07^{*}$ & $3.5 \pm 0.14^{*}$ & $4.85 \pm 0.11^{*}$ & $4.4 \pm 0.11^{*}$ \\
\hline
\end{tabular}

Significant at $* \mathrm{P}<0.05$; in all cases significance was tested with respect to 0 (control) using t-test, $(\mathrm{N}=3)$. 
$5^{\text {th }}$ instar in locusts eat large quantities, so after short exposure the shock of heavy metal in large quantity in short time leads to rapid response from the cells to express more Hsp 70 concentration to resist the heavy metal stress but at long period of exposure the cells may be adapted to the heavy metal stress after this long time and the expression of Hsp 70 becomes normal and near to the control results $[26,4]$.

Adaptive changes in Hsp expression over days also support the ecological significance of Hsps in natural populations [27,28]. In different species of Drosophila, it was shown that expression of Hsp 70 was lower in lines frequently or continuously exposed to severe stress [15-17]. The interpretation was that the costs of Hsp expression in populations frequently exposed to stress outweighed the benefits and that stress adaptation was achieved through some other means. The same pattern was subsequently found in natural population of Drosophila [29] and in soil invertebrates exposed to heavy metals [30]. According to these findings, the adaptation role of Hsps in connection to environmental stress resistance seems to occur during periods of relatively rare, unexpected extreme stress exposures and not during every day environmental fluctuations. Other mechanisms of adaptation to stressful conditions are selected for under chronic stressful environmental conditions [17,32].

Induction of Hsp 70 in response to exposure to heavy metals and physical stress has been reported in some invertebrates [29]. In Tigriopus brevicornis exposed to metals such as copper, nickel, silver and zinc leads to induction of metallothionein-like proteins [35]. In mollusks, the Hsp 70 biomarker has shown a good correlation with the level of pollution [36]. Hsp 70 levels were induced in samples collected from contaminated sites [37]. In vitro, studies have demonstrated that Hsp 70 induction is a cytoprotective response of cells to toxic chemical exposure $[38,39]$.

Insects living in contaminated environment have adapted to the level of existing contamination and not only do not synthesize more Hsp 70 proteins in response to heavy metal exposure, but rather decrease synthesis. While in other studies, the concentration of Hsp 70 detected in animals cells exposed to toxic substances was higher than in the control $[37,40]$. However, an increase in concentration of Hsp70 has not been observed in all species examined [29] or only at low concentrations of heavy metal exposure [37] and rather after short term than after chronic exposure [41].

The present work, based on the available data reveals that Hsps are ecologically relevant for all life stages. Correlation of Hsp expression levels and stress resistance might or might not exist between life stages.

Probably the up-regulation of Hsps in addition to be- ing an important part of the response to sudden extreme stress exposures is of ecological relevance on a much wider scale with respect to less severe but regular incidences of stress. Also the expression level of Hsps, in each species and population is a balance between benefits to resistance and costs, due to the impacts on growth, developmental rate and fertility that up-regulation of Hsp promotes.

The data presented in this work suggests the ability of using the induction and development of Hsp 70 in $S$. gregaria as a good biomarker for environment pollution by the heavy metals $(\mathrm{Cd} \& \mathrm{~Pb})$ at low contamination irrespective to the insect stage.

\section{REFERENCES}

[1] Schmidt, G.H. (1986) Use of grasshoppers as test animals for the ecotoxicological evaluation of chemicals in the soil. Agriculture, Ecosystem \& Environment, 16, 175-188. doi:10.1016/0167-8809(86)90003-4

[2] Warchałowska-Śliwa, E. and Maryańska-Nadachowska, A. (1991) Chromosome aberrations in a natural population of Tetrix tenuicornis (Sahlb.) (Tetrigidae: Orthoptra), Folia Biologica, 39, 5-15.

[3] Devkota, B. and Schmidt, G.H. (2000) Accumulation of heavy metals in food plants and grasshoppers from the Taigetos Mountains, Greece. Agriculture, Ecosystem \& Environment, 78, 85-91.

doi:10.1016/S0167-8809(99)00110-3

[4] Warchałowska-Śliwa, E., Niklinśka, M., Gőrlich, A., Michailova, P. and Pyza, E. (2005). Heavy metal accumulation, heat shock protein expression and cytogenetic changes in Tetrix tenuicornis (L.) (Tetrigidae, Orthoptera) from polluted areas. Environmental Pollution, 133, 373381. doi:10.1016/j.envpol.2004.05.013

[5] Migula, P. and Bińkowska, K. (1993) Feeding strategies of grasshoppers (Chorthippus sp.) on heavy metal contaminated plants. Science of the Total Environment, 10711083. doi:10.1016/S0048-9697(05)80112-3

[6] Augustyniak, M., Mesjasz-Przybytowicz, J., Nakonieczny, M., Dybowska, M., Przybylowicz, W. and Migula, P. (2002) Food relations between Chrysolina pardolina and Berkheya coddiia-nikckiel hyperaccumulator from South Africa ultramafic outcrops. Fresenius Environmental Bulletin, 11, 85-90.

[7] Muller, W.E., Koziol, C., Kurelec, B., Dapper, J., Batel, R. and Rinkevich, B. (1995) Combinatory effects of temperature stress and nonionic organic pollutant on stress protein (HSP 70) gene expression in fresh water sponge, Ephydatia fluviatilis. Environmental Toxicology and Chemistry, 14, 1203-1208.

[8] Welch, W.J. (1993) How cells respond to stress. Scientific American, 268, 56-64. doi:10.1038/scientificamerican0593-56

[9] Palleros, D.R., Welch, W.J., and Fink, A.L. (1991) Interaction of hsp70 with unfolded proteins: Effects of temperature and nucleotides on the kinetics of binding. Proceedings of the National Academy of Sciences, 88, 5719-5723. doi:10.1073/pnas.88.13.5719 
[10] Srivastava, P. (1993) Peptide-binding heat shock proteins in the endoplasmic reticulum: role in immune response to cancer and in antigen presentation. Advances in Cancer Research, 62, 153-177. doi:10.1016/S0065-230X(08)60318-8

[11] Moseley, P.L. (2000). Exercise, stress, and the immune conversation. Exercise and Sport Sciences Reviews, 28, 128-132.

[12] Bradford, M.A. (1976). Rapid and sensitive method for the quantitation of microgram quantities of protein utilizing the principle of protein-dye binding. Analytical Biochemistry, 72, 248-254. doi:10.1016/0003-2697(76)90527-3

[13] Laemmli, U.K. (1970) Cleavage of structural proteins during the assemble of the head of bacteriophage T4. Nature, 227, 680-685. doi:10.1038/227680a0

[14] Currie, S., Tufts, B.L., and Moyes, C.D. (1999) Influence of bioenergetic stress on heat shock protein gene expression in nucleated red blood cells of fish. American Journal of Physiology-regulatory Integrative and Comparative Physiology, 276, 990-996.

[15] Mizzen, L. A., and Welch, W. J. (1988) Characterization of the thermotolerant cell. I. Effects on protein synthesis activity and the regulation of heat-shock protein 70 expression. The Journal of Cell Biology, 106, 1105-1116. doi:10.1083/jcb.106.4.1105

[16] Bettencourt, B.R., Feder, F.E. and Cavicchi, S. (1999) Experimental evolution of Hsp 70 expression and thermotolerance in Drosophila melanogaster. Evolution, 53, 484-492. doi:10.2307/2640784

[17] Sorensen, J.G., Michalak, P., Justesen, J. and Loeschcke, V. (1999) Expression of the heat- shock protein HSP70 in Drosophila buzzatii lines selected for thermal resistance. Hereditas, 131, 155-164. doi:10.1111/j.1601-5223.1999.00155.x

[18] Lansing, E., Justesen, J. and Loeschcke, V. (2000) Variation in the expression of Hsp70, the major heat-shock protein, and thermotolerance in larval and adult selection lines of Drosophila melanogaster. The Journal of Thermal Biology, 25, 443-450. doi:10.1016/S0306-4565(00)00008-5

[19] Schlesinger, M.J. (1986) Heat shock proteins: The search for functions. The Journal of Cell Biology, 103, 321-325.

[20] Feder, M.E. and Hofman, G.E. (1999) Heat-shock proteins, molecular chaperones and stress response: Evolutionary and ecological Physiology. Annual Review of Physiology, 61, 243-282. doi:10.1146/annurev.physiol.61.1.243

[21] Lindquist, S. (1986) The heat-shock response. Annual Review of Biochemistry, 55, 1151-1191. doi:10.1146/annurev.bi.55.070186.005443

[22] Mahroof, R., Zhu, K.Y. and Subramanyam, B. (2005) Changes in expression of heat shock proteins in Tribolium castaneum (Coleoptera: Tenebrionidae) in relation to developmental stage, exposure time, and temperature. Annals of the Entomological Society of America, 98, 100-107. doi:10.1603/0013-8746(2005)098[0100:CIEOHS]2.0.CO; $\underline{2}$

[23] Ehrnsperger, M., Buchner, J. and Gaestel, M. (1997) Structure and function of small heat shock proteins. In: Fink, A.L., Goto, Y., Eds., Molecular Chaperones in the
Life Cycle of Proteins. Structure, Function and Mode of Action. Marcell Dekker, New York, 533-575.

[24] Mouchet, F., Baudrimont, M., Gonzalez, P., Cuenot, Y., Bourdineaud, J.P., Boudou, A. and Gauthier, L. (2006) Genotoxic and stress inductive potential of cadmium in Xenopus laevis larvae. Aquatic Toxicology, 78, 157-166. doi:10.1016/j.aquatox.2006.02.029

[25] Blechinger, S.R., Kusch, R.C., Haugo, K., Matz, C., Chivers, D.P. and Krone, P.H. (2007) Brief embryonic cadmium exposure induces a stress response and cell death in the developing olfactory system followed by long-term olfactory deficits in juvenile zebrafish. Toxicology and Applied Pharmacology, 224, 72-80. doi:10.1016/j.taap.2007.06.025

[26] Yousef, H.A., Afify, A., Hasan, H.M. and Abdel Meguid, A. (2010) DNA damage in hemocytes of Schistocerca gregaria (Orthoptera: Acrididae) exposed to contaminated food with cadmium and lead. Natural Science, 2, 292-297. doi:10.4236/ns.2010.24037

[27] Köhler, H.R. and Eckwert, H. (1997) The induction of stress proteins (hsp) in Oniscus asellus (Isopoda) as a molecular marker of multiple heavy metal exposure. 2 . Joint toxicity and transfer to field situations. Ecotoxicology, 6, 263-274. doi:10.1023/A:1018635012910

[28] Hofmann, G.E., and Somero, G.N. (1995) Evidence for protein damage at environmental temperatures: Seasonal changes in levels of ubiquitin conjugates and Hsp 70 in the interidal mussel. Journal of Experimental Biology, 198, 1509-1518.

[29] Pyza, E., Mak, P., Kramarz, P. and Laskowski, R. (1997) Heat shock proteins (Hsp 70) as biomarkers in ecotoxicological studies. Ecotoxicology and Environmental Safety, 38, 244-251. doi:10.1006/eesa.1997.1595

[30] Sørensen, J.G. and Loeschcke, V. (2001) Larval crowding in Drosophila melanogaster induces Hsp 70 expression, and leads to increased adult longevity and adult thermal stress resistance. All Aspects of Insect Physiology, 47, 1301- 1307. doi:10.1016/S0022-1910(01)00119-6

[31] Köhler, H.R., Zanger, M., Eckwert, H. and Einfeldt, I. (2000) Selection favours low Hsp70 levels in chronically metal-stressed soil arthropods. The Journal of Evolutionary Biology, 13, 569-582. doi:10.1046/j.1420-9101.2000.00210.x

[32] Sørensen, J.G. and Loeschcke, V. (2002) Natural adaptation to environmental stress via physiological clockregulation of stress resistance in Drosophila. Ecology Letters, 5, 16-19. doi:10.1046/j.1461-0248.2002.00296.x

[33] Kristensen, T.N., Dahlgaard, J. and Loeschcke, V. (2002) Inbreeding affects Hsp70 expression in two species of Drosophila even at benign temperatures. Evolutionary Ecology Research, 4, 1209-1216.

[34] Cheney, C.M. and Shearn A. (1983) Developmental regulation of imaginal disc proteins: Synthesis of a heat shock protein under non-heat shock conditions. Developmental Biology, 95, 325-330. doi:10.1016/0012-1606(83)90033-7

[35] Barka, S., Pavillon, J.F. and Amiard, J.C. (2001) Influence of different essential and nonessential metals on MTLP levels in the copepod Tigriopus brevicornis. Comp. Comparative Biochemistry and Physiology, 128C, 479-493.

[36] Wepener, V., vanVuren, J.H.J., Chatiza, F.P., Mbizi, Z., 
Slabbert, L. and Masola, B. (2005) Active biomonitoring in fresh water environments: Early warning signals from biomarker in assessing biological effects of diffuse sources of pollutants. Physics and Chemistry of the Earth, 3, 751-761.

[37] Köhler, H.R., Triebskorn, R., Stöcker, W., Kloetzel, P., and Alberti, G. (1992) The $70 \mathrm{KDa}$ heat shock protein (hsp 70) in soil invertebrates: A possible tool for monitoring environmental toxicants. Archives of Environmental Contamination and Toxicology, 22, 234-238.

[38] Hassen, W., Gollia, E.E., Baudrimont, I., Mobiob, A.T., Ladjimi, M.M., Creppy, E.E. and Bacha, H. (2005) Cytotoxicity and Hsp 70 induction in HepG2 cells in response to zearalenone and cytoprotection by sub-lethal heat shock. Toxicology, 207, 293-301. doi:10.1016/j.tox.2004.10.001

[39] Niu, P., Liu, L., Gong, Z., Tan, H., Wang, F., Yuan, J.,
Feng, Y., Wei, Q., Tanguay, R.M. and Wu, T. (2006) Over expressed heat shock protein 70 protects cells against DNA damage caused by ultraviolet $\mathrm{C}$ in a dose-dependent manner. Cell Stress Chaperones, 11, 162-169. doi:10.1379/CSC-175R.1

[40] Karouna-Renier, N.K. and Zehr, J.P. (2003) Short-term exposures to chronically toxic copper concentrations induce Hsp 70 proteins in midge larvae (Chironomus tentans). Science of the Total Environment, 312, 267-272. doi:10.1016/S0048-9697(03)00254-7

[41] Eckwert, H. and Köhler, H.R. (1997) The indicative value of the Hsp 70 stress response as a marker for metal effects in Oniscus asellus (Isopoda) field populations: variability between populations from metal-polluted and uncontaminated sites. Applied Soil Ecology, 6, 275-282. doi:10.1016/S0929-1393(97)00020-6 